\title{
A Note on the Standard Electron Transfer Potential at the Interface between Two Immiscible Electrolyte Solutions
}

\author{
Zdenĕk Samec \\ J. Heyrovský Institute of Physical Chemistry, Academy of Sciences of the Czech Republic, \\ Dolejškova 3, 18223 Prague 8, Czech Republic
}

Received August 11, 2009

\begin{abstract}
This article presents a brief note on the standard electron transfer potential at the interface between two immiscible electrolyte solutions (ITIES) in relation to the standard electrode potentials for redox reactions at electrodes. Based on the available experimental data, the scale of the standard electrode potentials for several redox systems in 1,2-dichloroethane is established, which can be used to evaluate the equilibrium constants of the homogeneous electron transfer reactions.
\end{abstract}

Keyword: interface between two immiscible electrolyte solutions, interfacial electron transfer, standard electron transfer potential, homogeneous electron transfer

\section{Introduction}

Studies of the interfacial electron transfer (ET) represent an essential part of electrochemistry at the interface between two immiscible electrolyte solutions (ITIES) ${ }^{1)}$. Following the first report on voltammetric measurements of the electron transfer between ferrocene $(\mathrm{Fc})$ in nitrobenzene and $\mathrm{Fe}(\mathrm{CN})_{6}{ }^{3-}$ in water ${ }^{2)}$,

$$
\mathrm{Fc}(\mathrm{o})+\mathrm{Fe}(\mathrm{CN})_{6}{ }^{3-}(\mathrm{w})=\mathrm{Fc}^{+}(\mathrm{o})+\mathrm{Fe}(\mathrm{CN})_{6}{ }^{4-}(\mathrm{w})
$$

a number of the ET reactions at the polarized ITIES have been investigated including various redox species such as metal biphtalocyanines ${ }^{3,4)}$, tetracyanoquinonedimethane ${ }^{5)}$, metal tetraphenylporphyrines $^{6)}$, substituted ferrocenes ${ }^{7)}$, ascorbic $\operatorname{acid}^{8)}$, flavin mononucleotide ${ }^{9)}$, and nicotinamide adenine dinucleotide ${ }^{10)}$. Mechanism and kinetics of the interfacial ET reactions has been a matter of earlier $^{11)}$ and more recent studies ${ }^{12-17)}$, cf. also ref. 18 for a review.

Although thermodynamics of ET at ITIES has been well understood, the concept of the standard electron transfer potential at ITIES is worth commenting. The aim of this work was to consider in brief this concept in relation to the standard electrode potentials of redox systems involved. 


\section{Equilibrium cell potential}

Let us consider the galvanic cell that can be used to study ET across ITIES, as shown by Scheme 1,

$$
\begin{array}{c||c|c|c||c} 
& & \mathrm{SY} & \mathrm{RX} \\
\mathrm{RE} & \mathrm{SX} & \mathrm{O} 1, \mathrm{R} 1 & \mathrm{O} 2, \mathrm{R} 2 \\
(\mathrm{w}) & \mathrm{o}) & \mathrm{RE}
\end{array}
$$

Scheme 1. Scheme of the galvanic cell for the study of ET across ITIES.

Here the single vertical bar represents the phase boundary, the double vertical bar represents the liquid junction, in which the liquid junction potential is assumed to be eliminated, RE's are conventional aqueous reference electrodes (e.g. saturated calomel or silver-silver chloride electrodes), and w (w') or o represent the aqueous or the organic phases containing RX (SX) or SY as electrolytes, respectively. Provided that equilibrium is established in both the partition of the ion $\mathrm{S}^{+}$at the $\mathrm{w}^{\prime} / \mathrm{o}$ interface and the electron transfer across the w/o interface between the redox couple O1/R1 in the phase o and the redox couple $\mathrm{O} 2 / \mathrm{R} 2$ in the phase $\mathrm{w}$, the cell potential attains its equilibrium (thermodynamic) value $E_{\text {eq. }}$. We shall assume that ET across ITIES can be described by

$n_{2} \mathrm{R} 1(\mathrm{o})+n_{1} \mathrm{O} 2(\mathrm{w})=n_{2} \mathrm{O} 1(\mathrm{o})+n_{1} \mathrm{R} 2(\mathrm{w})$

where the stoichiometric coefficients $n_{1}$ and $n_{2}$ are the numbers of electrons in the partial ET reactions

$$
\begin{aligned}
& \mathrm{O} 1(\mathrm{o})+n_{1} \mathrm{e}^{-}=\mathrm{R} 1(\mathrm{o}) \\
& \mathrm{O} 2(\mathrm{w})+n_{2} \mathrm{e}^{-}=\mathrm{R} 2(\mathrm{w})
\end{aligned}
$$

In order to establish the relationship between $E_{\text {eq }}$ and the activities of the oxidized and reduced forms of the redox systems in $\mathrm{w}$ and o, we can express $E_{\text {eq }}$ as the sum of the inner (Galvani) potential differences at the individual interfaces of the cell above. A simpler and a more instructive way is to consider an inert metal membrane $\mathrm{M}$ inserted into the cell to separate the phases $\mathrm{w}$ and $\mathrm{o}$, as shown by Scheme 2,

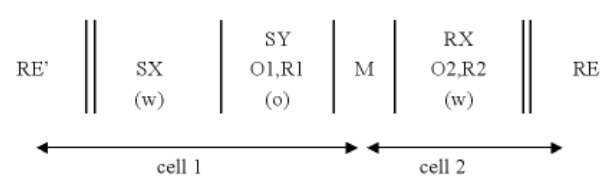

Scheme 2. A modification of galvanic cell shown by the Scheme 1 with the metallic membrane M separating the phases $\mathrm{w}$ and $\mathrm{o}$.

The galvanic cell shown by Scheme 2 can be viewed upon as being composed of two conventional galvanic cells 1 and 2 that are composed of an oxidation-reduction electrode and a reference electrode. Since the introduction of the metal membrane has no effect on the equilibrium cell potential, the expression for $E_{\text {eq }}$ is obtained immediately as the difference of two Nernst electrode potentials, i.e.,

$$
\begin{aligned}
& E_{\mathrm{eq}}=\phi^{R E}-\phi^{R E^{\prime}}=E^{0}+\left(R T / n_{1} n_{2} F\right) \ln K_{i n}= \\
& E_{\mathrm{O} 1 / \mathrm{R} 1}^{0}\left(\mathrm{RE}^{\prime}, \mathrm{w}\right)-E_{\mathrm{O} 2 / \mathrm{R} 2}^{0}(\mathrm{RE}, \mathrm{w})+ \\
& \left(R T / n_{1} n_{2} F\right) \ln K_{i n}
\end{aligned}
$$

where $E^{0}$ is the standard electron transfer potential for the interfacial ET reaction in a given cell (Scheme 1), $K_{i n}$ is the equilibrium constant of the interfacial ET reaction,

$$
K_{i n}=\left(a_{\mathrm{O} 1}^{\mathrm{o}} / a_{\mathrm{R} 1}^{\mathrm{o}}\right)^{n_{2}}\left(a_{\mathrm{R} 2}^{\mathrm{w}} / a_{\mathrm{O} 2}^{\mathrm{w}}\right)^{n_{1}}
$$

$a_{\mathrm{i}}^{\prime} \mathrm{s}$ are the activities and $E_{\mathrm{O} / \mathrm{R} 1}^{0}\left(\mathrm{RE}^{\prime}, \mathrm{w}\right)$ and $E_{\mathrm{O} 2 / \mathrm{R} 2}^{0}(\mathrm{RE}, \mathrm{w})$ are the corresponding standard 
electrode potentials, which are referred to the aqueous reference electrodes $\mathrm{RE}^{\prime}$ and $\mathrm{RE}$, respectively. It is noteworthy that the value of the standard potential $E_{\mathrm{O} / \mathrm{R} 1}^{0}\left(\mathrm{RE}^{\prime}, \mathrm{w}\right)$, which is an experimentally accessible quantity, depends on the composition of the phases w' and o determining the equilibrium potential difference at the $\mathrm{w}^{\prime} \mathrm{o}_{\mathrm{o}}$ interface.

Previously, we have used Eq. (5) to compare the values of the standard electron transfer potential $E^{0}$ measured for the reaction (1) in the cell shown by the Scheme 1, and evaluated from the standard electrode potentials $E_{\mathrm{O} 1 / \mathrm{R} 1}^{0}\left(\mathrm{RE}^{\prime}, \mathrm{w}\right)$ and $E_{\mathrm{O} 2 / \mathrm{R} 2}^{0}(\mathrm{RE}, \mathrm{w})$ for the redox systems $\mathrm{Fc}^{+} / \mathrm{Fc}$ and $\mathrm{Fe}(\mathrm{CN})_{6}{ }^{3-} / \mathrm{Fe}(\mathrm{CN})_{6}{ }^{4-}$, respectively. ${ }^{19)}$ Theoretical and practical aspects of the membrane cell (Scheme 2) have been investigated by Osakai et al. $^{12)}$

\section{Equilibrium potential difference at ITIES}

Thermodynamic considerations on the interfacial ET across ITIES can be also based on the equilibrium condition, e.g. for the reaction (1),

$$
n_{2} \tilde{\mu}_{\mathrm{R} 1}(\mathrm{o})+n_{1} \tilde{\mu}_{\mathrm{O} 2}(\mathrm{w})=n_{2} \tilde{\mu}_{\mathrm{O} 1}(\mathrm{o})+n_{1} \tilde{\mu}_{\mathrm{R} 2}(\mathrm{w})
$$

where $\tilde{\mu}_{\mathrm{i}}(\mathrm{s})$ is the electrochemical potential of the particle $\mathrm{i}$ in the solvent s. Eq. (7) leads to the expression for the equilibrium potential difference $\Delta_{o}^{\mathrm{w}} \phi_{e q}$ at ITIES,

$$
\Delta_{\mathrm{o}}^{\mathrm{w}} \phi_{e q}=\Delta_{\mathrm{o}}^{\mathrm{w}} \phi^{0}+\left(R T / n_{1} n_{2} F\right) \ln K_{i n}
$$

In an analogy with definition of the standard ion transfer potential ${ }^{1)}, \Delta_{\mathrm{o}}^{\mathrm{w}} \phi^{0}$ can be considered as the standard electron transfer potential, which is given by
$\Delta_{\mathrm{o}}^{\mathrm{w}} \phi^{0}=\left[n_{2}\left(\mu_{\mathrm{O} 1}^{0, \mathrm{o}}-\mu_{\mathrm{R} 1}^{0, \mathrm{o}}\right)-n_{1}\left(\mu_{\mathrm{O} 2}^{0, \mathrm{w}}-\mu_{\mathrm{R} 2}^{0, \mathrm{w}}\right)\right] / n_{1} n_{2} F$

where $\mu_{i}^{0, s}$ is the standard chemical potential of the particle $\mathrm{i}$ in the solvent $\mathrm{s}$. Upon introducing the standard chemical potentials of molecular hydrogen $\left(\mu_{\mathrm{H}_{2}}^{0}\right)$ and of proton $\left(\mu_{\mathrm{H}^{+}}^{0, \mathrm{~s}}\right)$, Eq. (9) can be rewritten as ${ }^{1)}$

$\Delta_{\mathrm{o}}^{\mathrm{w}} \phi^{0}=\bar{E}_{\mathrm{O} 1 / \mathrm{R} 1}^{0}(\mathrm{SHE}, \mathrm{w})-E_{\mathrm{O} 2 \mathrm{R} 2}^{0}(\mathrm{SHE}, \mathrm{w})$

where $\bar{E}_{\mathrm{O} 1 / \mathrm{R} 1}^{0}(\mathrm{SHE}, \mathrm{w})$ and $E_{\mathrm{O} 2 \mathrm{R} 2}^{0}(\mathrm{SHE}, \mathrm{w})$ are the standard electrode potentials for the redox systems $\mathrm{O} 1 / \mathrm{R} 1$ and $\mathrm{O} 2 / \mathrm{R} 2$, respectively, referred to the standard hydrogen electrode (SHE) in water,

$\bar{E}_{\mathrm{O} 1 \mathrm{R} 1}^{0}(\mathrm{SHE}, \mathrm{w})=\left[\mu_{\mathrm{O} 1}^{0, \mathrm{o}}-\mu_{\mathrm{R} 1}^{0, \mathrm{o}}+\left(n_{1} / 2\right) \mu_{\mathrm{H}_{2}}^{0}-n_{1} \mu_{\mathrm{H}^{+}}^{0, \mathrm{w}}\right] / n_{1} F$

$$
E_{\mathrm{O} 2 / \mathrm{R} 2}^{0}(\mathrm{SHE}, \mathrm{w})=\left[\mu_{\mathrm{O} 2}^{0, \mathrm{w}}-\mu_{\mathrm{R} 2}^{0, \mathrm{w}}+\left(n_{2} / 2\right) \mu_{\mathrm{H}_{2}}^{0}-n_{2} \mu_{\mathrm{H}^{+}}^{0, \mathrm{w}}\right] / n_{2} F
$$

Eq. (10) might imply that a non-measurable quantity, i.e. $\Delta_{\mathrm{o}}^{\mathrm{w}} \phi^{0}$, could be expressed as a difference of two measurable quantities, i.e. $\bar{E}_{\mathrm{O} / \mathrm{R} 1}^{0}(\mathrm{SHE}, \mathrm{w})$ and $E_{\mathrm{O} / \mathrm{R} 2}^{0}(\mathrm{SHE}, \mathrm{w})$. However, this is not so. While $E_{\mathrm{O} 2 / \mathrm{R} 2}^{0}(\mathrm{SHE}, \mathrm{w})$ has the same physical meaning as the measurable standard potential $E_{\mathrm{O} 2 / \mathrm{R} 2}^{0}(\mathrm{RE}, \mathrm{w})$ above (with $\mathrm{RE}=\mathrm{SHE}$ ), $\bar{E}_{\mathrm{O} / R 1}^{0}(\mathrm{SHE}, \mathrm{W})$ is not measurable being related to $E_{\mathrm{O} / \mathrm{R} 1}^{0}\left(\mathrm{RE}^{\prime}, \mathrm{w}\right)$ through $^{20)}$

$$
\begin{aligned}
& \bar{E}_{\mathrm{O} 1 / \mathrm{R} 1}^{0}(\mathrm{SHE}, \mathrm{w})=E_{\mathrm{O} 1 / \mathrm{R} 1}^{0}(\mathrm{SHE}, \mathrm{w})+\Delta_{\mathrm{o}}^{\mathrm{w}^{\prime}} \phi= \\
& E_{\mathrm{O} 1 / \mathrm{R} 1}^{0}\left(\mathrm{RE}^{\prime}, \mathrm{w}\right)+E_{\mathrm{RE}^{\prime}}(\mathrm{SHE})+\Delta_{\mathrm{o}}^{\mathrm{w}^{\prime}} \phi
\end{aligned}
$$

where $E_{\mathrm{RE}}(\mathrm{SHE})$ is the electrode potential of the reference electrode RE' referred to SHE in water, and $\Delta_{\mathrm{o}}^{\mathrm{w}^{\prime}} \phi$ is the potential difference between the reference phase w' and o in the galvanic cell above (Scheme 1 and Scheme 2). 
An alternative expression for the standard potential difference $\Delta_{\mathrm{o}}^{\mathrm{w}} \phi^{0}$ can be obtained upon introducing the standard electrode potential for the redox system $\mathrm{O} 1 / \mathrm{R} 1, E_{\mathrm{O} 1 / \mathrm{R} 1}^{0}(\mathrm{SHE}, \mathrm{o})$ that is referred to SHE in the organic phase $o,{ }^{1)}$

$$
\bar{E}_{\mathrm{O} 1 / \mathrm{R} 1}^{0}(\mathrm{SHE}, \mathrm{w})=E_{\mathrm{O} 1 / \mathrm{R} 1}^{0}(\mathrm{SHE}, \mathrm{o})+\Delta_{\mathrm{o}}^{\mathrm{w}} \phi_{\mathrm{H}^{+}}^{0}
$$

where $\Delta_{\mathrm{o}}^{\mathrm{w}} \phi_{\mathrm{H}^{+}}^{0}$ is the standard ion transfer potential for proton. The latter is related to the standard Gibbs energy of proton transfer, $\Delta G_{\mathrm{tr}, \mathrm{H}^{+}}^{0, \mathrm{w} \rightarrow}$,

$$
\Delta_{\mathrm{o}}^{\mathrm{w}} \phi_{\mathrm{H}^{+}}^{0}=\left(\mu_{\mathrm{H}^{+}}^{0, \mathrm{o}}-\mu_{\mathrm{H}^{+}}^{0, \mathrm{w}}\right) / F=\Delta G_{\mathrm{tr}, \mathrm{H}^{+}}^{0, \mathrm{w} \rightarrow} / F
$$

Eq. (10) can be then written as

$$
\Delta_{\mathrm{o}}^{\mathrm{w}} \phi^{0}=E_{\mathrm{O} 1 / \mathrm{R} 1}^{0}(\mathrm{SHE}, \mathrm{o})-E_{\mathrm{O} 2 / \mathrm{R} 2}^{0}(\mathrm{SHE}, \mathrm{w})+\Delta_{\mathrm{o}}^{\mathrm{w}} \phi_{\mathrm{H}^{+}}^{0}
$$

Unlike $\bar{E}_{\mathrm{O} 1 / \mathrm{R} 1}^{0}(\mathrm{SHE}, \mathrm{w})$, the standard electrode potential $E_{\mathrm{O} 1 / \mathrm{R} 1}^{0}(\mathrm{SHE}, \mathrm{o})$ is a measurable quantity, at least in principle, vide infra.

\section{Definition and significance of $E_{\mathrm{O} 1 / \mathrm{R} 1}^{0}(\mathrm{SHE}, \mathrm{o})$}

The standard electrode potential $E_{\mathrm{O} 1 / \mathrm{R} 1}^{0}(\mathrm{SHE}, \mathrm{o})$ can be defined as the equilibrium potential of the cell described by Scheme 3,

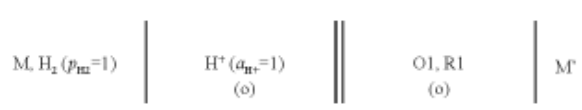

Scheme 3. Scheme of the galvanic cell composed of the O1/R1 redox electrode and the standard hydrogen electrode both in the organic solvent 0 .

under the standard conditions. This potential is determined by the standard Gibbs energy $\Delta \boldsymbol{G}^{0}$ for the cell reaction

$$
\left(n_{1} / 2\right) \mathrm{H}_{2}+\mathrm{O} 1(\mathrm{o})=n_{1} \mathrm{H}^{+}(\mathrm{o})+\mathrm{R} 1(\mathrm{o})
$$

i.e.,

$$
\begin{aligned}
& E_{\mathrm{O} 1 / \mathrm{R} 1}^{0}(\mathrm{SHE}, \mathrm{o})=-\Delta G^{0} / n_{1} F= \\
& {\left[\mu_{\mathrm{O} 1}^{0, \mathrm{o}}-\mu_{\mathrm{R} 1}^{0, \mathrm{o}}+\left(n_{1} / 2\right) \mu_{\mathrm{H}_{2}}^{0}-n_{1} \mu_{\mathrm{H}^{+}}^{0, \mathrm{o}}\right] / n_{1} F}
\end{aligned}
$$

cf. Eq. (11). The galvanic cell, which is composed of the half-cells that are standard hydrogen electrodes in water and an organic solvent has been previously considered to clarify the significance of the $\mathrm{pH}$ scale in organic solvents in relation to the thermodynamic proton transfer functions, e.g. to $\Delta G_{\mathrm{tr}, \mathrm{H}^{+}}^{0, \mathrm{w} \rightarrow \mathrm{o} 22)}$.

The equilibrium constant $K_{\text {hom }}$ of a homogeneous electron transfer reaction, such as

$n_{2} \mathrm{R} 1(\mathrm{o})+n_{1} \mathrm{O} 2(\mathrm{o})=n_{2} \mathrm{O} 1(\mathrm{o})+n_{1} \mathrm{R} 2(\mathrm{o})$

can be related to the difference of the standard electrode potentials $E_{\mathrm{O} 2 / \mathrm{R} 2}^{0}(\mathrm{SHE}, \mathrm{o})$ and $E_{\mathrm{O} 1 / \mathrm{R} 1}^{0}(\mathrm{SHE}, \mathrm{o})$, i.e.,

$$
\begin{aligned}
& K_{\mathrm{hom}}=\exp \left(-\Delta G^{0} / R T\right)=a_{\mathrm{O} 1}^{n_{2}} a_{\mathrm{R} 2}^{n_{1}} / a_{\mathrm{R} 1}^{n_{2}} a_{\mathrm{O} 2}^{n_{1}} \\
& \Delta G_{\mathrm{hom}}^{0}=-n_{1} n_{2} F\left[E_{\mathrm{O} 2 / \mathrm{R} 2}^{0}(\mathrm{SHE}, \mathrm{o})-E_{\mathrm{O} 1 / \mathrm{R} 1}^{0}(\mathrm{SHE}, \mathrm{o})\right]
\end{aligned}
$$

It is worth noticing that $K_{\text {hom }}$ can be analogously related to the difference of the standard potentials $\bar{E}_{\mathrm{O} 2 / \mathrm{R} 2}^{0}(\mathrm{SHE}, \mathrm{w})$ and $\bar{E}_{\mathrm{O} 1 / \mathrm{R} 1}^{0}(\mathrm{SHE}, \mathrm{w})$.

\section{Scale of the standard electrode potentials in organic solvents}

In principle, the values of $E_{\mathrm{O} 1 / \mathrm{R} 1}^{0}(\mathrm{SHE}, \mathrm{o})$ could be obtained by the equilibrium potential measurements of the cell described by Scheme 3. A reliable SHE in the phase o however is difficult to 
realize. On the other hand, $E_{\mathrm{O} / \mathrm{R} 1}^{0}(\mathrm{SHE}, \mathrm{o})$ could be estimated using one of the following procedures.

First, for some redox systems $E_{\mathrm{O} 1 / \mathrm{R} 1}^{0}(\mathrm{SHE}, \mathrm{o})$ can be inferred from the known values of the standard electrode potential $E_{\mathrm{O} 1 / \mathrm{R} 1}^{0}(\mathrm{SHE}, \mathrm{w})$ referred to SHE in water and the standard Gibbs energy of transfer of the redox components from water to the organic solvent. This is the case e.g. of the $\mathrm{O}_{2} / \mathrm{H}_{2} \mathrm{O}$ redox system, for which $E_{\mathrm{O} / \mathrm{Rl}}^{0}(\mathrm{SHE}, \mathrm{o})$ is given by the standard Gibbs energy for the cell reaction,

$$
2 \mathrm{H}_{2}(\mathrm{~g})+\mathrm{O}_{2}(\mathrm{~g})=2 \mathrm{H}_{2} \mathrm{O}(\mathrm{o})
$$

Obviously,

$$
E_{\mathrm{O}_{2} / \mathrm{H}_{2} \mathrm{O}}^{0}(\mathrm{SHE}, \mathrm{o})=E_{\mathrm{O}_{2} \mathrm{H}_{2} \mathrm{O}}^{0}(\mathrm{SHE}, \mathrm{w})-\Delta \mathrm{G}_{\mathrm{tr}, \mathrm{H}_{2} \mathrm{O}}^{0, \mathrm{w} \rightarrow \mathrm{O}} / 2 F
$$

where $\Delta \mathrm{G}_{\mathrm{tr}, \mathrm{H}_{2} \mathrm{O}}^{0, \mathrm{O} \rightarrow \mathrm{O}}$ is the standard Gibbs energy of water transfer from $\mathrm{w}$ to $\mathrm{o}$, which can be estimated e.g. from the solubility $s_{\mathrm{H}_{2} \mathrm{O}}^{\mathrm{o}}$ of water in the organic solvent, $\Delta \mathrm{G}_{\mathrm{tr}, \mathrm{H}_{2} \mathrm{O}}^{0, \mathrm{w} \rightarrow \mathrm{o}}=-R T \ln s_{\mathrm{H}_{2} \mathrm{O}}^{\mathrm{o}}$. For 1,2-dichloroethane (DCE) $s_{\mathrm{H}_{2} \mathrm{O}}^{\mathrm{o}}=0.11 \mathrm{M}^{1}$ ), which yields $\Delta \mathrm{G}_{\mathrm{tr}, \mathrm{H}_{2} \mathrm{O}}^{0, \mathrm{~W} \rightarrow \mathrm{O}}=5.5 \mathrm{~kJ} \mathrm{~mol}^{-1}$, and $E_{\mathrm{O}_{2} / \mathrm{H}_{2} \mathrm{O}}^{0}(\mathrm{SHE}, \mathrm{o})=$ $1.200 \mathrm{~V}\left(E_{\mathrm{O}_{2} / \mathrm{H}_{2} \mathrm{O}}^{0}(\mathrm{SHE}, \mathrm{w})=1.229 \mathrm{~V}\right)$.

Second, $E_{\mathrm{O} / R 1}^{0}(\mathrm{SHE}, \mathrm{o})$ can be obtained by using Eq. (13) and Eq. (14), and the value of the standard potential $E_{\mathrm{O} / \mathrm{R} 1}^{0}\left(\mathrm{RE}^{\prime}, \mathrm{w}\right)$, which can be measured with the cell 1 in Scheme 2. In this way, $\bar{E}_{\mathrm{O} 1 / \mathrm{R} 1}^{0}(\mathrm{SHE}, \mathrm{w})$ was evaluated for 1,1'-dimethylferrocene oxidation process from voltammetric measurements on the Au electrode in 9 organic solvents, and for other ferrocene redox systems in 1,2-dichloroethane (DCE) ${ }^{20)}$. The procedure involves the application of the extrathermodynamic tetraphenylarsonium tetraphenylborate hypothesis to evaluate the interfacial potential difference $\Delta_{\mathrm{o}}^{\mathrm{w}^{\prime}} \phi$ and the standard ion transfer potential for proton $\Delta_{\mathrm{o}}^{\mathrm{w}} \phi_{\mathrm{H}^{+}}^{0}$. The DCE data $^{20,21)}$ and the corresponding values of $E_{\text {O1/R1 }}^{0}(\mathrm{SHE}, \mathrm{o})$ obtained using $\Delta_{\mathrm{o}}^{\mathrm{w}} \phi_{\mathrm{H}^{+}}^{0}=0.549 \mathrm{~V}^{1)}$ are summarized in Table 1.

Table 1. Values of $\bar{E}_{\mathrm{O} / \mathrm{R} 1}^{0}(\mathrm{SHE}, \mathrm{w})$ and $E_{\mathrm{O} / \mathrm{R} 1}^{0}(\mathrm{SHE}, \mathrm{o})$ (in parentheses) for the ferrocene redox systems in DCE.

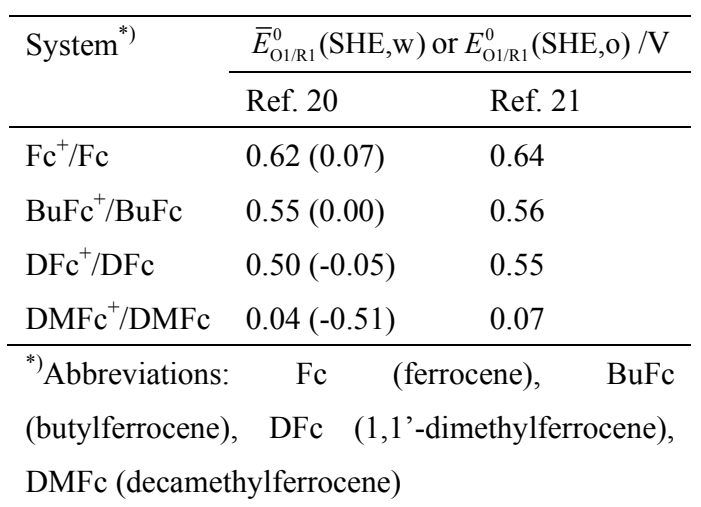
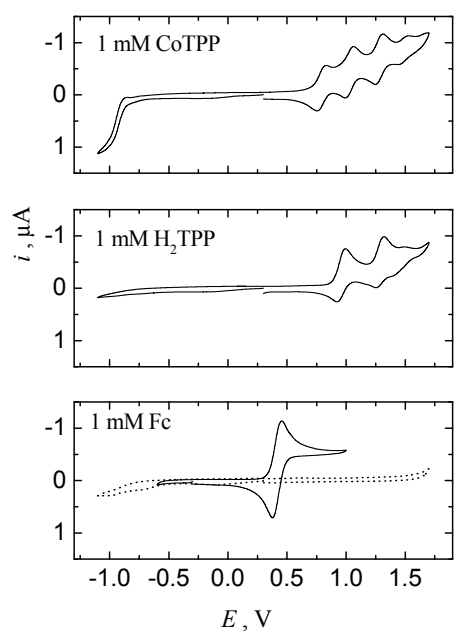

Fig. 1. Cyclic voltammograms $(20 \mathrm{mV} / \mathrm{s})$ of Co (II) tetraphenylporphyrin (CoTPP), tetraphenylporphyrin $\left(\mathrm{H}_{2} \mathrm{TPP}\right)$ and ferrocene $(\mathrm{Fc})$ at $\mathrm{Au}$ electrode in deaerated DCE solution of $0.1 \mathrm{M}$ tetrabutylammonium hexafluorophosphate. Background current is shown by the dotted line. ${ }^{23)}$ 
Third, one of the ferrocene derivatives can be used as an internal voltammetric standard, i.e. the reversible half-wave potential for the investigated redox system is referred to the reversible half-wave potential of the ferrocene redox system, both measured voltammetrically in the same galvanic cell. This method is demonstrated in Figure 1 showing the cyclic voltammograms of $\mathrm{Co}$ (II) tetraphenylporphyrin (CoTPP), tetraphenylporphyrin ligand $\left(\mathrm{H}_{2} \mathrm{TPP}\right)$ and ferrocene $(\mathrm{Fc})$. The reversible half-wave potentials inferred from the voltammograms and the value of $E_{\mathrm{Fc}^{+} / \mathrm{Fc}}^{0}(\mathrm{SHE}, \mathrm{o})=$ $0.07 \mathrm{~V}$ (Table 1) for the $\mathrm{Fc}^{+} / \mathrm{Fc}$ redox system yields the values of the standard electrode potentials $E_{\mathrm{O} 1 / \mathrm{R} 1}^{0}(\mathrm{SHE}, \mathrm{o})=0.39 \mathrm{~V}$ and $0.62 \mathrm{~V}$ for the $\mathrm{CoTPP}^{+} /$ CoTPP and $\mathrm{H}_{2} \mathrm{TPP}^{+} / \mathrm{H}_{2} \mathrm{TPP}$ redox systems. Thus, from the thermodynamic point of view both systems can serve as a redox catalyst for the $\mathrm{O}_{2}$ reduction to $\mathrm{H}_{2} \mathrm{O}$ by any of the ferrocene derivatives.

\section{Conclusions}

Standard electron transfer potential $E^{0}$ for an interfacial ET across ITIES can be defined in two ways. First definition refers to the equilibrium cell potential and is described by Eq. (5). Advantage of this definition is that $E^{0}$ is a measurable quantity, which can be expressed and evaluated as the difference of two measurable standard electrode potentials for the redox systems involved. Disadvantage of this definition is that $E^{0}$ depends on the composition of the reference electrode phases including the organic solvent phase. Second definition refers to the equilibrium potential difference at ITIES and is described by Eq. (8). Advantage of this definition is that the standard electron transfer potential $\Delta_{\mathrm{o}}^{\mathrm{w}} \phi^{0}$ is independent of the composition of the reference electrodes.
Disadvantage is that $\Delta_{0}^{\mathrm{w}} \phi^{0}$ is not a measurable quantity. This quantity can be evaluated using an extra-thermodynamic hypothesis in Eq. (10) or Eq. (16). The scale of the standard potentials $\bar{E}_{\mathrm{O} / \mathrm{R} 1}^{0}(\mathrm{SHE}, \mathrm{w})$ and $E_{\mathrm{O} / \mathrm{R} 1}^{0}(\mathrm{SHE}, \mathrm{o})$ referred to the standard hydrogen electrode in water and organic solvent, respectively, can be established, which can be used to evaluate the equilibrium constants of the corresponding homogeneous electron transfer reaction in organic solvents immiscible with water.

\section{Acknowledgements}

This work was supported by Grant Agency of the Czech Republic (grant no. 203/07/1257).

\section{References}

1) Z. Samec, Pure Appl. Chem., 76, 2147 (2004).

2) Z. Samec, V. Mareček, J. Weber, J. Electroanal. Chem. 96, 245 (1979).

3) G. Geblewicz, D.J. Schiffrin, J. Electroanal. Chem. 244, 27 (1988).

4) V.J. Cunnane, G. Geblewicz, D.J. Schiffrin, J. Electroanal. Chem. 247, 203 (1988).

5) S. Kihara, M. Suzuki, K. Maeda, K. Ogura, M. Matsui, Z. Yoshida, J. Electroanal. Chem. 271, 107 (1989).

6) Y. Cheng, D.J. Schiffrin, J. Electroanal. Chem. 314, 153 (1991).

7) V.J. Cunnane, G. Geblewicz, D.J. Schiffrin, Electrochim. Acta. 40, 3005 (1995).

8) M. Suzuki, S. Umetani, M. Matsui, S. Kihara, $J$. Electroanal. Chem. 420, 119 (1997).

9) M. Suzuki, M. Matsui, S. Kihara, J. Electroanal. Chem. 438, 147 (1997).

10) H. Ohde, K. Maeda, Y. Yoshida, S. Kihara, Electrochim. Acta 44, 23 (1998).

11) J. Hanzlik, Z. Samec, J. Hovorka, J. Electroanal. Chem. 216, 303 (1987). 
12) H. Hotta, N. Akagi, T. Sugihara, S. Ichikawa, T. Osakai, Electrochem. Commun. 4, 472 (2002).

13) H. Hotta, S. Ichikawa, T. Sugihara, T. Osakai, $J$. Phys. Chem. B 107, 9717 (2003).

14) H. Tatsumi, H. Katano, J. Electroanal. Chem. 577, 59 (2005).

15) H. Tatsumi, H. Katano, J. Electroanal. Chem. 592, 121 (2006).

16) H. Tatsumi, H. Katano, J. Electroanal. Chem. 614, 61 (2008).

17) T. Osakai, M. Okamoto, T. Sugihara, K. Nakatani, J. Electroanal.Chem. $\mathbf{6 2 8}, 27$ (2009).
18) H. Tatsumi, Rev. Polarogr. 54, 89 (2008).

19) Z. Samec, V. Mareček, J. Weber, D. Homolka, J. Electroanal. Chem. 126, 105 (1981).

20) J. Langmaier, A. Trojánek, Z. Samec, J. Electroanal. Chem. 616, 57 (2008).

21) N. Eugster, D.J. Fermin, H.H. Girault, J. Phys. Chem. B 106, 3428 (2002).

22) O. Popovych, R.P.T. Tomkins, Nonaqueous Solution Chemistry, Wiley, New York, 1981, pp. 180-182.

23) J. Langmaier, unpublished data. 